\title{
Obezitede Güncel Yaklaşımlar: Kahverengi Yağ Dokusu Transplantasyonu ve Vagal Sinir Blokajı
}

\author{
Recent Approach in Obesity: Brown Adipose Tissue Transplantation and Vagal Nerve Blockage
}

Yasemin Açar ${ }^{1}$, Gamze Akbulut ${ }^{2}$

Geliş tarihi/Received: 26.02 .2020 • Kabul tarihi/Accepted: 02.09.2020

\section{ÖZET}

Obezite, vücutta anormal miktarda yağ birikimi ile karakterize, kronik bir hastalıktır. Son yıllarda Türkiye’de ve dünyada obezite prevalansı giderek artmaktadır. Bu artışla birlikte obezite ile ilişkili komorbidite riskinin azaltılması için yeni tedavi seçeneklerine duyulan ihtiyaçlar da önem kazanmaktadır. Kahverengi yağ dokusu transplantasyonu ve vagal sinir blokajı bu yaklaşımlardan bazılarıdır. Ratlar üzerinde yapılmış mevcut çalışmalarla, kahverengi yağ dokusu transplantasyonunun obezite ve diyabet üzerinde olumlu etkileri olabileceği belirtilmektedir. Bariatrik cerrahiye alternatif bir tedavi yöntemi sağlamak amacıyla geliştirilen vagal sinir blokajının ise vücut ağırlık kaybı, kan basıncı, kan lipitleri ve glisemik kontrol gibi parametreler üzerinde olumlu etkileri bulunmaktadır. Bu derleme kahverengi yağ dokusu transplantasyonu ve vagal sinir blokajının obezite üzerine etkilerini incelemek amacıyla yazılmıştır.

Anahtar kelimeler: Adipoz doku, obezite, kahverengi yă̆ dokusu transplantasyonu, vagal sinir blokajı

\begin{abstract}
Obesity is a chronic disease characterized by abnormal accumulation of fat in the body. In recent years in Turkey and in the world, obesity prevalence is increasing. With this increase, the need for new treatment options are gaining importance to reduce the risk of obesity-related comorbidity. Brown adipose tissue transplantation and vagal nerve blockage are some of these approaches. It is stated in the current studies on rats that brown adipose tissue transplantation may have positive effects on obesity and diabetes. Vagal nerve blockage, developed to provide an alternative treatment method to bariatric surgery, has positive effects on parameters such as body weight loss, blood pressure, blood lipids and glycemic control. This review was written to examine the effects of brown adipose tissue transplantation and vagal nerve blockage on obesity.
\end{abstract}

Keywords: Adipose tissue, obesity, brown fat transplantation, vagal nerve blockage

1. İletişim/Correspondence: Ondokuz Mayıs Üniversitesi, Sağlık Bilimleri Fakültesi, Beslenme ve Diyetetik Bölümü, Samsun, Türkiye

E-posta: dytyaseminacar@gmail.com • 『 ㄴ https://orcid.org/0000-0002-3567-0384
2. Gazi Üniversitesi, Sağlık Bilimleri Fakültesi, Beslenme ve Diyetetik Bölümü, Ankara, Türkiye • • \ttps://orcid.org/0000-0003-0197-1573 


\section{GİRIŞ}

Obezite, enerji alımı ve harcaması arasındaki dengesizlikten kaynaklanan bir hastalıktır. Hatalı yaşam tarzı alışkanlıkları, aşırı besin tüketimi ve fiziksel inaktivite gibi faktörler nedeniyle obezite prevalansı endişe verici bir şekilde artmaktadır. Obezite prevalansındaki artış ile birlikte tip 2 diyabet, kardiyovasküler hastalıklar ve kanser dâhil olmak üzere obezite ile ilişkili komorbiditelerin riskindeki artışın önüne geçilebilmesi amacıyla yeni tedavi yaklaşımlarına duyulan ihtiyaç artmaktadır (1). $\mathrm{Bu}$ derleme yazıda, obeziteye yönelik alternatif tedavi yaklaşımları olan kahverengi yağ dokusu transplantasyonu ve vagal sinir blokajının obezite üzerine etkileri güncel literatür eşliğinde incelenmiştir.

\section{Adipoz Doku}

Enerji alımı ve harcamasında, metabolik fonksiyonların düzenlenmesinde görev alan adipoz doku önemli bir organdır (1). Adipoz dokunun, obezite ile ilişkili hastalıkların mekanizmasında kilit bir rolü olduğu ortaya çıkmıştır (2).

Adipoz doku, aktif bir endokrin doku gibi uyaranlara yanıt olarak leptin, adiponektin veya resistin gibi hormonları ve tümör nekroz faktörü (TNF-a), interlökin IL-6, IL-1 $\beta$ gibi inflamatuvar sitokinleri salgllamaktadır. $\mathrm{Bu}$ nedenle adipoz doku; enerji harcaması, iştah durumu, insülin duyarlılığı, bağışıklık ve inflamasyon ile endokrin ve üreme fonksiyonları gibi önemli metabolik yolları kontrol eden karmaşık ve aktif bir organ gibi görev yapmaktadır (2). Beyaz yağ dokusu (white adipose tissue-WAT) ve kahverengi yağ dokusu (brown adipose tissue-BAT) olmak üzere iki çeşit yağ dokusu bulunmaktadır (3).

\section{Beyaz Yağ Dokusu}

Beyaz yağ dokusu (WAT), metabolizma ve insülin direncini düzenleyen çok sayıda hormon ve sitokin salgılamaktadır (4). Vücutta depolandığı yere göre beyaz yağ dokusu visseral ve subkutan olmak üzere iki gruba ayrılmaktadır. Visseral yăg dokusu, karın içi organların çevresinde bulunurken subkutan yağ dokusu ise tüm vücutta deri altında bulunmaktadır (5).

Beyaz yağ dokusu vücudun enerji deposudur ve fazla enerji beyaz yağ dokusunda trigliserit şeklinde depolanmaktadır. Pozitif enerji dengesinin devam etmesi durumunda trigliseritler karaciğer ve iskelet kası gibi diğer dokulara geçerek bu dokularda birikmektedir. Bu birikim, bozulmuş glukoz metabolizması, insülin direnci, tip 2 diyabet ve metabolik sendrom gibi çeşitli hastalıkların oluşmasına neden olmaktadır (6).

\section{Kahverengi Yağ Dokusu}

Kahverengi yağ dokusu (BAT), yetişkin vücudunun supraklavikular, paravertebral, servikal, aksillar ve mediastinal bölgelerinde yer alan, isı üretiminde görevli bir yağ dokusudur (5). Bir endokrin organ olarak BAT, yağ asitleri ve glukoz gibi kaynakları kullanarak enerji homeostazını düzenlemekte, ayrıca glukoz ve lipit metabolizmasında da önemli rol oynamaktadır (7). Bunun yanısıra; TNF- $\alpha$, adiponektin, leptin, fibroblast büyüme faktörü 21 (FGF-21) gibi soğuğa adaptasyon ve adrenerjik stimülasyon için gerekli olan sitokin ve hormon benzeri molekülleri salgilamaktadır (4).

Beyaz yağ dokusu ile karşılaştırıldığında, kahverengi yağ dokusu daha küçük yağ partikülleri ve bol miktarda mitokondri içeren bir yapıya sahiptir (5). Beyaz yağ dokusunun aksine kahverengi yağ dokusu, lipit oksidasyonu ile ısı üreterek termoregülasyonun düzenlenmesinde görevlidir (3). Beyaz ve kahverengi yağ dokusunun özellikleri Tablo 1'de verilmiştir.

Başlangıçta, insanlarda kahverengi yağ dokusunun yalnızca yenidoğan döneminde termogenezde önemli bir rol oynadığı düşünülmekteydi. Ancak yapılan çalışmalarla yetişkin bireylerde soğuğa maruziyet ve sinir sisteminin sempatik aktivasyonuyla uyarılan ve düşünülenden daha yüksek miktarda aktif kahverengi yağ dokusunun bulunduğu gösterilmiştir. Bu durum 
Tablo 1. Beyaz ve kahverengi yağ dokusunun karşılaştırılması (3)

\begin{tabular}{lll}
\hline Özellikleri & Beyaz Yağ Dokusu & Kahverengi Yağ Dokusu \\
\hline Fonksiyonu & Enerji depolama & Isı üretimi \\
Morfolojisi & Tekli lipit damlacıkları & Çoklu küçük vakuoller \\
& Değişken miktarda mitokondri & Bol miktarda mitokondri \\
Karakteristik proteini & Leptin & UCP1* \\
Gelişimi & Myf5**- negatif progenitör hücrelerinden & Myf5- pozitif progenitör hücrelerinden \\
İnsan verileri & Artı̧ı, obezite ile ilgili hastalık riskini artırır & Artışı, obezite ile ilgili hastalık riskini azaltır \\
Yaşlanmanın etkisi & Toplam vücut ağırlığına göre yaşla birlikte artar & Yaşla birlikte azalır \\
\hline${ }^{*}$ UCP1: Uncoupling protein 1 & ${ }^{* *}$ Myf5: Myogenic factor 5 &
\end{tabular}

BAT aktivasyonunun metabolik sağlığı geliştirmedeki rolüne olan ilgiyi artırmıştır $(8,9)$.

Yoneshiro et al. (10) tarafından yapılan bir çalışmada, kahverengi yağ dokusunun insanlardaki metabolik aktiviteleri florodeoksiglukoz-pozitron emisyon tomografisi (FDG-PET) ve bilgisayarlı tomografi (CT) kullanılarak ölçülmüştür. Bireylerin altı hafta boyunca $19^{\circ} \mathrm{C}$ 'de günlük iki saat süreyle soğuğa maruz kalmasının, enerji harcaması ve BAT aktivitesini artırıp vücut yağ kütlesinde azalmaya neden olduğu bildirilmiştir.

İnsanlarda ve kemirgenlerde soğuğa maruziyet, BAT aktivasyonu için en güçlü fizyolojik uyaranlardan biridir. Soğuğun BAT üzerindeki uyarıcı etkilerine, duyusal nöronlarda reseptör kanallarının uyarılması ile başlatılan sempatik sinir sistemi aktivasyonu vasıtasıyla aracılık ettiği bilinmektedir. Sıçan ve fare modellerinde BAT, organizmanin soğuk ortama adapte olmasını sağlamak amacıyla ısı üretmekte ve enerji harcamasını artırarak obezite riskini azaltmaktadır. $\mathrm{Bu}$ yol ayrıca, kapsaisin ve kapsinoidler gibi bazı besin bileşenleri tarafından da aktive edilmektedir $(10,11)$. Reseptör kanallarının kapsinoidler tarafından uyarılması, farelerde BAT termojenezinin güçlendirilmesi ve termogenezin temel bir molekülü olan ayırıcı protein 1'in (uncoupling protein-UCP1) regülasyonunda etkilidir (12).

\section{Kahverengi Yağ Dokusu Transplantasyonu}

Fare modelleri ile yapılmış çalışmalarda, kahverengi yağ dokusu transplantasyonunun metabolik sağlık üzerinde yararlı etkilere sahip olduğu gösterilmiştir $(13,14)$.
Stanford et al. (15) tarafından yapılan bir çalışmada, BAT naklinin glukoz toleransı ve insülin duyarlılığını artırdığı, vücut ağırlığını azalttığı ve yüksek yağlı diyete bağlı olarak oluşan insülin direncini tersine çevirdiği bildirilmiştir. Nakledilen yağ dokusunun antidiyabetik etkisinin, insülin benzeri büyüme faktörü 1 (insulin-like growth factor-IGF1) salınımından kaynaklandığı öne sürülmektedir (16).

Kahverengi yă̆ dokusu transplantasyonu, WAT, karaciğer, pankreas, kalp ve kemik gibi periferik dokuları hedef alan ve aynı zamanda merkezi sinir sistemiyle etkileşerek sistemik metabolizmayı etkileyen endokrin faktörler salgllamaktadır (17). Transplante edilen nakil modellerindeki vücut ağırlığı, glukoz homeostazı ve insülin duyarlılığındaki gelişmeler nakledilen dokudaki bu endokrin etki sonucunda oluşmaktadır (15).

Nakledilen BAT, IL-6, adiponektin veya potansiyel sitokinleri salgılayarak endojen BAT aktivitesini artırmaktadır. Bu bulgular, artmış BAT kütlesinin, obezite karşıtı bir etki sağlayan enerji harcamasını artırdığını göstermiştir. Bununla birlikte, kahverengi yağ dokusu transplantasyonunun günümüzde insanlar üzerinde yapılmış herhangi bir uygulaması bulunmamaktadır (7).

Payab et al. (18) tarafindan kahverengi yağ transplantasyonu ile ilgili ratlar üzerinde yapılmış çalışmalar bir meta-analizde derlenmiş ve sonuçları Tablo 2'de verilmiştir.

$\mathrm{Bu}$ metaanalizde kahverengi yă dokusu transplantasyonu sonucunda ratlarda kan glukozunun 
Tablo 2. Kahverengi yağ transplantasyonu ile ilgili yapılmış çeşitli çalışmaların özeti (18)

\begin{tabular}{|c|c|c|}
\hline Referans ve yılı & Takip süresi & Sonuçlar \\
\hline Shankar et al. (14) & 4 hafta & $\begin{array}{l}\text { Vücut ağırlığı ve açlık glukozunda azalma } \\
\text { Enerji harcaması, } \mathrm{O}_{2} \text { tüketimi, } \mathrm{CO}_{2} \text { üretimi, ısı üretimi ve insülin hassasiyetinde } \\
\text { artış, glukoz toleransında iyileşme }\end{array}$ \\
\hline Chen et al. (19) & 3 hafta & İnsülin hassasiyetinde artma, glukoz toleransında iyileşme \\
\hline Wu et al. (20) & 6 ay & $\begin{array}{l}\text { Vücut ağırlı̆̆ı, yağ kütlesi ve açlık glukozunda azalma } \\
\text { Yağsız kütle ve enerji harcamasında artma }\end{array}$ \\
\hline Liu et al. (21) & 12 hafta & $\begin{array}{l}\text { Yağ kütlesi, kan glukozu, adipozit boyutu, TG* ve IL-6** düzeylerinde azalma } \\
\text { Enerji harcaması, oksijen tüketimi ve vücut sıcaklığında artma }\end{array}$ \\
\hline
\end{tabular}

*IL-6: İnterlökin 6, ${ }^{* *}$ TG: Trigliserit

azalıp glukoz toleransınıniyileştiği, poliüri, polidipsive polifaji gibi diyabet semptomlarının normale döndüğü bildirilmiştir. Ayrıca adipoz doku inflamasyonu, kan lipitleri, glukoz toleransı, kolesterol ve insülin hassasiyetinde iyileşme sağlandığı gösterilmiştir. Yapılan çalışmalar sadece ratlar üzerinde kısa dönemli olarak gerçekleştirildiği için metabolik sonuçlarının daha iyi aydınlatılabilmesi adına uzun dönemli çalışmalara ihtiyaç olduğu bildirilmiştir (18).

\section{Vagal Sinir Blokajı}

Kahverengi yağ dokusu transplantasyonuna ek olarak obezite üzerine olumlu etkileri bulunan güncel yaklaşımlardan biri de vagal sinir blokajıdır (22).

Otonom sinir sistemi, merkezi sinir sistemi ile gastrointestinal sistem arasındaki iletişimde, kısa ya da uzun süreli vücut ağırlığının düzenlenmesinde merkezi bir rol oynamaktadır (23). Obezite ile ilgili bazı komplikasyonlar otonom sinir sisteminin aktivitesine bağlıdır. Otonom sinir sistemi, herhangi bir kontrol mekanizması olmadan hareket eden afferent motor sistemidir. Vücudun her yerine dağılmış farklı yapılar arasındaki hareketi koordine etmektedir. Sempatik ve parasempatik bölümlerden oluşan otonom sinir sistemi, özellikle iştahın düzenlenmesi yolu ile homeostazın korunması için önemlidir (22).

Vagus siniri, sindirim sistemi ve merkezi sinir sistemi arasındaki otonom bağlantıyı sağlayan 10. kranial sinirdir. Besin tüketimi ve enerji metabolizmasının düzenlenmesinde önemli görevleri bulunmaktadır (24). Vagus sinirinin \%10-20'si, mide asidi ve sindirim enzimlerinin salgılanması ve mide hareketliliğini kontrol eden, elastik liflerden oluşmaktadır. Kalan \%80-90’lık bölümü ise doygunluğu ve doygunluğu düzenleyen sinyaller gönderen afferent liflerden oluşmaktadır (25).

Vagal afferent nöronlar, gastrointestinal sistem ve beyin arasındaki bilgi aktarımını sağlayarak beslenme durumu hakkında bilgi vermekte ve bağırsak ile beyin arasındaki en önemli bağlantıyı oluşturmaktadır (26). Besin alımı durumunda, enteroendokrin hücreler besin alımını engelleyen anorektik hormonlar salgılamaktadır. Herhangi bir besin alımı olmadığında ise besin alımını uyaran oreksijenik hormonlar salgllanmaktadır. Vagal afferent nöronlar, bu hormonların ve doygunluğun algılanmasında görev yapan bağırsak terminallerindeki kemoreseptör ve mekanoreseptörlerin uyarımını sağlamaktadır (27). Enteroendokrin hücreler, vagal afferent nöronlar tarafından algılanabilen nöroendokrin sinyalleme modeli üreterek öğünün sonlandırılmasını sağlamak için beyine negatif geri bildirim göndermektedir (28).

Besin alımı ve enerji metabolizması arasındaki ilişkinin daha iyi anlaşılmasıyla, iştahı düzenleyen peptidler ve vagus sinirinin elektriksel uyarımında görev alan implante edilebilir cihazlar, klinik çalışmalarda obezite için yeni tedavi seçenekleri olarak araştırılmaktadır (24).

\section{Vagal Sinirin Aralıklı Blokajı}

Vagal sinir blokajı cihazı (VBlock), Beden Kütle İndeksi (BKI) $40-45 \mathrm{~kg} / \mathrm{m}^{2}$ veya $35-40 \mathrm{~kg} / \mathrm{m}^{2}$ olan ve 
en az bir obezite ile ilişkili komorbid hastalığı olan bireylerde, bariatrik cerrahiye göre daha az invaziv bir girişim olduğu için alternatif bir yöntem olarak geliştirilmiştir. Cihazın yerleştirilmesi, standart laparoskopik cerrahi tekniklerle yapılmaktadır (22). Vagal blokajın gelişimi, obeziteyi iyileştirebileceği ve hastaların açlık duygularını kontrol etmelerinde yardımcı olacağı düşüncesine dayanmaktadır (29).

Ticari ismi Maestro Şarj Edilebilir Sistem (Maestro Rechargeable System) olan vagal sinir blokajı cihazı, karın içi sinir gövdelerine düşük enerjili, yüksek frekanslı, aralıklı, elektrik enerjisi vermektedir. Çalışma süresi 5 dakika blokaj ve 5 dakika bloke edilmemiş bir döngü halinde, günde en az 12 saat süresince gerçekleşmektedir (30,31). Vagal sinir blokajı cihazı Gıda İlaç Dairesi (FDA) tarafından 2015 yllında onaylanmıştır (25). Bu cihaz, ön ve arka vagus sinirlerine bağlanan iki elektrot ve akım veren şarj edilebilir bir üreteçten oluşmaktadır (25). Cihaz, sinir gövdelerine 5000 Hertzlik bir frekansta 0-8 mA arasında değişen sabit akım sağlamak üzere tasarlanmıştır. Maksimum şarj yoğunluğu ise 8 mA'dir (32).

Gönderilen yüksek frekanslı elektrik enerjisi sayesinde vagal sinir sinyallerinde kesinti olmakta ve bu durum da mide boşalmasında gecikmeye ve dolayısıyla erken doygunluk sağlanması ve açlık hissinin azalmasına katkı sağlamaktadır. Ayrıca, bu blokajla pankreasın ekzokrin sekresyonunun da önemli ölçüde azaldığı gösterilmiştir (25).

Vagal sinir blokajı cihazı; karaciğer sirozu, portal hipertansiyon, özofagus varisleri ve hiatal herni gibi durumlarda kontraendikedir. Cerrahi komplikasyon açısından yüksek risk altında bulunan veya kalp pili gibi kalıcı implante edilmiş cihazlara sahip olan hastaların VBlock cihazı açısından uygun olmadığı bildirilmiştir (32).

Yapılan bir çalışmada, VBloc tedavisinin diyet kompozisyonunu değiştirmeden erken doygunluk sağlayarak enerji alımının azalmasına neden olduğu gösterilmiştir (33). Bu durum özellikle geleneksel bariatrik cerrahi ile ilişkili ciddi diyet değişikliklerini istemeyen hastalar için umut verici bir bulgudur (25).

Vagal sinir blokajı cihazı, obez bireylerde önemli vücut ağırlığı kaybına yol açmakta ve enerji alımını önemli ölçüde azaltmaktadır. Toplam enerji alımı, implantasyondan sonra hızla azalmakta ve en az iki yıl boyunca korunmaktadır. Açlık ve iştahı değerlendirmek için görsel analog ölçekleri kullanılarak cihazın doygunluğu artırdığı ve açlığı azalttığı bulunmuştur. $\mathrm{Bu}$ nedenle, günlük enerji alımındaki azalmanın, öğünler sırasında ve arasında azalmış besin alımından kaynaklanması muhtemeldir. Cihazın besin tercihleri üzerindeki etkisi ise henüz belirlenmemiştir (27).

Apovian et al. (30) tarafından yürütülen çift kör, randomize kontrollü bir çalışmada, BKİ>35 kg/m² olan bireylerde, iki yll süresince VBloc tedavisi ile aralıklı vagal blokaj gerçekleştirilmiştir. Çalışma sonunda anlamlı vücut ağırlığı kaybı, obeziteye eşlik eden komorbid durumlarda düzelme, kan basıncl, kan lipitleri ve glisemik kontrolde iyileşme, beslenme alışkanlıkları ve yaşam kalitesi gibi parametrelerde düzelme sağlandığı ve minimal düzeyde yan etki oluştuğu gözlenmiştir. Benzer şekilde Morton et al. (22) tarafından yürütülen çift kör, randomize kontrollü klinik bir çalışmada, BKI’si $35-40 \mathrm{~kg} / \mathrm{m}^{2}$ arasında değişen 53 obez birey VBlock cihazı ile 12 ay süresince takip edilmiş ve çalışma sonucunda ortalama vücut ağırlığı kaybının \%11 olduğu bildirilmiştir. Shikora et al. (34) tarafından tip 2 diyabetli obez hastaların, VBlock cihazı takılarak bir yıl boyunca takip edildiği bir çalışmada; ortalama vücut ağırlığı kaybının \%25 kadar olduğu, HbA1c'nin \%1.0 ve sistolik kan basıncının 8 mmHg azaldığı görülmüştür.

VBlock cihazının yan etkileri bariatrik cerrahiye göre daha az şiddetlidir. Cihazın implante edildiği kişilerde herhangi bir ölüm gözlenmemekle birlikte en yaygın şikayetlerin implant bölgesinde hafif veya orta derecede ağrı, mide bulantısı, disfaji, kramp ve şişkinlik olduğu bildirilmiştir (27). 
Tüm bu etkilerinin yanı sıra vagal sinir blokajının etkinliğini diğer obezite tedavileriyle karşlaştırmak ve vücut ağırlığı kaybı ile güvenliğin uzun süreli etkilerini değerlendirmek için ek çalışmalara ihtiyaç duyulduğu vurgulanmaktadır $(22,31,35,36)$.

\section{SONUÇ VE ÖNERİLER}

Kahverengi yağ dokusu transplantasyonu ve vagal sinir blokajı obeziteyi önlemeye yönelik geliştirilen güncel tedavi yaklaşımlarıdır. Çalışmalarda BAT transplantasyonunun obezite ve diyabet üzerinde olumlu etkileri bildirilmiş; ancak yapılan çalışmalar ağırlıklı olarak kemirgenler üzerinde yürütülmüştür. Mevcut çalışmaların sonuçları, BAT transplantasyonunun ratlarda enerji harcamasını önemli ölçüde artırarak adipoziteyi azalttığını ve glukoz homeostazını iyileştirdiğini göstermektedir. $\mathrm{Bu}$ özellikleri ile obezite ve diyabet gibi ilgili hastalıkları hedef alan yeni tedavi seçeneklerinin geliştirilmesinde farklı bir yol açabilmektedir. Bir diğer tedavi yaklaşımı olan vagus siniri blokajının ise vücut ağırlık kaybı, gastrik motilite, postprandiyal kan glukozu üzerine olumlu etkileri yapılan çalışmalarda vurgulanmaktadır. Her iki yaklaşımın olası mekanizmalarının daha iyi aydınlatılabilmesi ve uzun dönem etkilerinin doğrulanması için insanlar üzerinde yapılmış daha fazla klinik çalışmaya gereksinim duyulmaktadır.

Çıkar çatışması - Conflict of interest: Yazarlar çıkar çatışması olmadığını beyan ederler. - The authors declare that they have no conflict of interest.

\section{KAYNAKLAR}

1. White JD, Dewal RS, Stanford KI. The beneficial effects of brown adipose tissue transplantation. Mol Aspects Med. 2019;68(2019):74-81.

2. Calderon-Dominguez M, Mir JF, Fucho R, Weber M, Serra D, Herrero L. Fatty acid metabolism and the basis of brown adipose tissue function. Adipocyte. 2016;5(2):98118.

3. Saely CH, Geiger K, Drexel H. Brown versus white adipose tissue: A mini-review. Gerontology. 2012;58(1):15-23.

4. Gomez-Hernandez A, Beneit N, Diaz-Castroverde S, Escribano O. Differential role of adipose tissues in obesity and related metabolic and vascular complications. Int J Endocrinol. 2016;2016:1216783.

5. Choe SS, Huh JY, Hwang IJ, Kim JI, Kim JB. Adipose tissue remodeling: Its role in energy metabolism and metabolic disorders. Front Endocrinol. 2016;7:30.

6. Lidell ME, Enerbäck S. Brown adipose tissue-a new role in humans? Nat Rev Endocrinol. 2010;6(6):319.

7. Dong M, Lin J, Lim W, Jin W, Lee HJ. Role of brown adipose tissue in metabolic syndrome, aging, and cancer cachexia. Front Med. 2018;12(2):130-8.

8. Cypess AM, Lehman S, Williams G, Tal I, Rodman D, Goldfine $\mathrm{AB}$, et al. Identification and importance of brown adipose tissue in adult humans. $\mathrm{N}$ Engl J Med. 2009;360(15):1509-17.

9. Halpern B, Mancini MC, Halpern A. Brown adipose tissue: What have we learned since its recent identification in human adults. Arq Bras Endocrinol Metabol. 2014;58(9):889-99.

10. Yoneshiro T, Aita S, Matsushita M, Kayahara T, Kameya $\mathrm{T}$, Kawai Y, et al. Recruited brown adipose tissue as an antiobesity agent in humans. J Clin Invest. 2013;123(8):3404-8

11. Betz MJ, Enerbäck S. Human brown adipose tissue: What we have learned so far. Diabetes. 2015;64(7):2352-60

12. Ono K, Tsukamoto-Yasui M, Hara-Kimura $\mathrm{Y}$, Inoue $\mathrm{N}$, Nogusa Y, Okabe Y, et al. Intragastric administration of capsiate, a transient receptor potential channel agonist, triggers thermogenic sympathetic responses. J Appl Physiol. 2011;110(3):789-98.

13. Jimenez-Pavon D, Corral-Perez J, Sánchez-Infantes D, Villarroya F, Ruiz JR, Martinez-Tellez B. Infrared thermography for estimating supraclavicular skin temperature and bat activity in humans: A systematic review. Obesity 2019;27(12):1932-49.

14. Shankar K, Kumar D, Gupta S, Varshney S, Rajan S, Srivastava A, et al. Role of brown adipose tissue in modulating adipose tissue inflammation and insulin resistance in high-fat diet fed mice. Eur J Pharmacol. 2019;854:354-64.

15. Stanford KI, Middelbeek RJ, Townsend KL, An D, Nygaard EB, Hitchcox KM, et al. Brown adipose tissue regulates glucose homeostasis and insulin sensitivity. J Clin Invest. 2012;123(1).

16. Gunawardana SC, Piston DW. Reversal of type 1 diabetes in mice by brown adipose tissue transplant. Diabetes. 2012;61(3):674-82.

17. Villarroya F, Cereijo R, Villarroya J, Giralt M. Brown adipose tissue as a secretory organ. Nat Rev Endocrinol. 2017;13(1):26.

18. Payab M, Abedi M, Heravani NF, Hadavandkhani M, Arabi M, Tayanloo-Beik A, et al. Brown adipose tissue transplantation as a novel alternative to obesity 
treatment: A systematic review. Int J Obes. 2020:1-13.

19. Chen L, Wang L, Li Y, Wuang L, Liu Y, Pang N, et al. Transplantation of normal adipose tissue improves blood flow and reduces inflammation in high fat fed mice with hindlimb ischemia. Front Physiol. 2018;9:197.

20. Wu R, Liu X-m, Sun J-g, Chen H, Ma J, Dong M, et al. DJ-1 maintains energy and glucose homeostasis by regulating the function of brown adipose tissue. Cell Discov. 2017;3(1):1-18.

21. Liu X, Wang S, You Y, Meng M, Zheng Z, Dong M, et al. Brown adipose tissue transplantation reverses obesity in Ob/Ob mice. Endocrinol. 2015;156(7):2461-9.

22. Morton JM, Shah SN, Wolfe BM, Apovian CM, Miller CJ, Tweden KS, et al. Effect of vagal nerve blockade on moderate obesity with an obesity-related comorbid condition: The ReCharge study. Obes Surg. 2016;26(5):983-9.

23. Guarino D, Nannipieri M, Iervasi G, Taddei S, Bruno RM. The role of the autonomic nervous system in the pathophysiology of obesity. Front Physiol. 2017;8:665.

24. Ueno H, Nakazato M. Mechanistic relationship between the vagal afferent pathway, central nervous system and peripheral organs in appetite regulation. J Diabetes Investig. 2016;7(6):812-8.

25. Hwang SS, Takata MC, Fujioka K, Fuller W. Update on bariatric surgical procedures and an introduction to the implantable weight loss device: The Maestro Rechargeable System. Med Devices (Auckl). 2016;9:291.

26. Dockray G, Burdyga G. Plasticity in vagal afferent neurones during feeding and fasting: Mechanisms and significance. Acta Physiol. 2011;201(3):313-21.

27. de Lartigue G. Role of the vagus nerve in the development and treatment of diet-induced obesity. J Physiol. 2016;594(20):5791-815.

28. Raybould HE. Gut chemosensing: Interactions between gut endocrine cells and visceral afferents. Auton Neurosci. 2010;153(1-2):41-6.

29. Sarr MG, Billington CJ, Brancatisano R, Brancatisano A,
Toouli J, Kow L, et al. The EMPOWER study: Randomized, prospective, double-blind, multicenter trial of vagal blockade to induce weight loss in morbid obesity. Obes Surg. 2012;22(11):1771-82.

30. Apovian CM, Shah SN, Wolfe BM, Ikramuddin S, Miller CJ, Tweden KS, et al. Two-year outcomes of vagal nerve blocking (VBloc) for the treatment of obesity in the ReCharge trial. Obes Surg. 2017;27(1):169-76.

31. Papasavas P, El Chaar M, Kothari SN. American Society for Metabolic and Bariatric Surgery position statement on vagal blocking therapy for obesity. Surg Obes Relat Dis. 2016;12(3):460-461.

32. U.S. Food and Drug Administration. Summary of Safety and Effectiveness Data (SSED): Maestro Rechargeable System. Available at: http://www.accessdata.fda.gov/ cdrh_docs/pdf13/P130019B.pdf. Accessed August 18, 2020.

33. Herrera MF, Burton DD, Pantoja JP, SanchezLeenheer S, Bachmann B, Valdovinos MA, et al. M1268 intermittent vagal blocking with an implantable device reduces Maximum Tolerated Volume (MTV) during a standardized nutrient drink test in obese subjects. Gastroenterol. 2009;136(5):A-386.

34. Shikora SA, Toouli J, Herrera MF, Kulseng B, Brancatisano $\mathrm{R}$, Kow L, et al. Intermittent Vagal Nerve Block for improvements in obesity, cardiovascular risk factors, and glycemic control in patients with type 2 diabetes mellitus: 2-year results of the VBLOC DM2 study. Obes Surg. 2016;26(5):1021-8.

35. Ikramuddin S, Blackstone RP, Brancatisano A, Toouli J, Shah SN, Wolfe BM, et al. Effect of reversible intermittent intra-abdominal vagal nerve blockade on morbid obesity: The ReCharge randomized clinical trial. JAMA. 2014;312(9):915-22.

36. Shikora SA, Wolfe BM, Apovian CM, Anvari M, Sarwer DB, Gibbons RD, et al. Sustained weight loss with vagal nerve blockade but not with sham: 18-month results of the ReCharge Trial. J Obes. 2015;2015:365604. 